\title{
Correction to: Conservative solutions for progress: on solution types when combining QCA with in-depth Process-Tracing
}

\author{
Priscilla Álamos-Concha ${ }^{1}$ (D) Valérie Pattyn ${ }^{2} \cdot$ Benoît Rihoux $^{3}$. \\ Benjamin Schalembier ${ }^{4}$. Derek Beach ${ }^{5} \cdot$ Bart Cambré $^{6}$
}

Published online: 28 September 2021

(c) The Author(s) 2021

\section{Correction to: Quality \& Quantity https://doi.org/10.1007/s11135-021-01191-x}

The words "Online Resource 1" should be read as "Appendix 3" throughout the article. The original article has been corrected.

The original article can be found online at https://doi.org/10.1007/s11135-021-01191-x.

Priscilla Álamos-Concha

p.alamosconcha@fm.ru.nl

Valérie Pattyn

v.e.pattyn@fgga.leidenuniv.nl

Benoît Rihoux

benoit.rihoux@uclouvain.be

Benjamin Schalembier

Benjamin.schalembier@vlaanderen.be

Derek Beach

derek@ps.au.dk

Bart Cambré

bart.cambre@ams.ac.be

1 Nijmegen School of Management, Radboud University, Heyendaalseweg 41, 6525 AJ Nijmegen, The Netherlands

2 Institute of Public Administration, Leiden University, The Hague, The Netherlands

3 Department of Political and Social Sciences, Institute of Political Science Louvain-Europe (ISPOLE), University of Louvain, Place Montesquieu, 1 bte L2.08.07, B-1348 Louvain-la-Neuve, Belgium

4 Department of Work and Social Economy, Flemish Government, Brussels, Belgium

5 Department of Political Science, Aarhus University, Bartholins Allé 7, building 1332, 222, 8000 Aarhus C, Denmark

6 Antwerp Management School/Universith of Antwerp/Management Center Innsbruck, Antwerp Management School, Boogkeers 5, 2000 Antwerpen, Belgium 
Open Access This article is licensed under a Creative Commons Attribution 4.0 International License, which permits use, sharing, adaptation, distribution and reproduction in any medium or format, as long as you give appropriate credit to the original author(s) and the source, provide a link to the Creative Commons licence, and indicate if changes were made. The images or other third party material in this article are included in the article's Creative Commons licence, unless indicated otherwise in a credit line to the material. If material is not included in the article's Creative Commons licence and your intended use is not permitted by statutory regulation or exceeds the permitted use, you will need to obtain permission directly from the copyright holder. To view a copy of this licence, visit http://creativecommons.org/licenses/by/4.0/.

Publisher's Note Springer Nature remains neutral with regard to jurisdictional claims in published maps and institutional affiliations. 